UDK 811.163.42’367.335

Izvorni znanstveni rad

Rukopis primljen 8. I. 2019.

Prihvaćen za tisak 4. VII. 2019.

Irina Masnikosa

https://doi.org/10.31724/rihjj.45.2.14

Filozofski fakultet Sveučilišta u Zagrebu

Ivana Lučića 3, HR-10000 Zagreb

imasniko@ffzg.hr

\title{
Mirjana Tonković
}

Filozofski fakultet Sveučilišta u Zagrebu

Ivana Lučića 3, HR-10000 Zagreb

mirjana.tonkovic@ffzg.hr

\section{Anita Peti-Stantić}

Filozofski fakultet Sveučilišta u Zagrebu Ivana Lučića 3, HR-10000 Zagreb

anita.peti-stantic@ffzg.hr

\section{O OBLIKU I TIPU INFORMACIJE U JEZIČNOM PROCESIRANJU: ODABIR ANTECEDENTA ELIPSE GLAGOLSKE SKUPINE U HRVATSKOME ${ }^{1}$}

U literaturi je pokazano kako se sintaktička struktura, za razliku od značenja iskaza, vrlo kratko zadržava u pamćenju, osobito nakon rečenične granice (Caplan 1972, Jarvella 1971). Unatoč tomu postoje istraživanja koja pokazuju kako sintaktička struktura koja prethodi elipsi glagolske skupine utječe na njezinu obradu i interpretaciju (Hankamer i Sag 1976, Shapiro i Hestvik 1995). Frazier i Clifton (2005) formuliraju hipotezu glavne tvrdnje prema kojoj se novi jezični materijal povezuje s glavnom tvrdnjom prethodne rečenice ako je ona lako dostupna te hipotezu domene koordinacije prema kojoj je u obradi koordinirane strukture dostupna čitava koordinirana struktura ili samo recentna sastavnica. Te su hipoteze eksperimentalno potvrđene u engleskom jeziku ispitivanjem odabira antecedenta eliptičnih rečenica koje otvaraju mogućnost višestruke interpretacije. U ovom su radu hipoteze glavne tvrdnje i domene koordinacije eksperimentalno testirane u hrvatskom jeziku ispitivanjem odabira antecedenta eliptičnih rečenica kojima prethode zavisnosložene (Tina je otišla kući nakon što je popila piće. I Marija je. // Nakon što je popila piće, Tina je otišla kući. I Marija je.) i nezavisnosložene rečenice (Tina je otišla kući $i$ popila piće. I Marija je. // Tina je popila piće i otišla kući. I Marija je.). U ispitivanju je dodatno mjereno i vrijeme reakcije ispitanika. Rezultati eksperimenta pokazuju da su ispitanici, neovisno

\footnotetext{
1 Rad je izrađen u okviru projekta HRZZ-IP-2016-06-1210 Modeliranje mentalne gramatike hrvatskoga: ograničenja informacijske strukture.
} 
o vrsti rečenice koja im je prethodila, dominantno birali koordiniranu strukturu kao antecedent elipse. Uz to, u interpretaciji elipse nakon zavisnosloženih rečenica zabilježen je utjecaj glavne tvrdnje, ali i utjecaj recentnosti na odabir antecedenta.

\section{Uvod}

U ovom se radu eksperimentalno ispituju preferencije govornika pri odabiru antecedenta elipse glagolske skupine s mogućnošću višestruke interpretacije. Istraživanja u engleskom jeziku (Hankamer i Sag 1976, Shapiro i Hestvik 1995, Garnham i dr. 1998, Frazier i Clifton 2005) pokazuju kako na obradu i interpretaciju elipse utječe tip sintaktičke strukture koji joj prethodi. Provedenim eksperimentom testirane su razlike $\mathrm{u}$ interpretaciji eliptičnih rečenica kojima prethode zavisnosložene rečenice (primjeri 1a i lb) te nezavisnosložene rečenice (primjer 1c).

(1) a. Tina je otišla kući nakon što je popila piće. I Marija je.

b. Nakon što je popila piće, Tina je otišla kući. I Marija je.

c. Tina je popila piće i otišla kući. I Marija je.

Razumijevanje eliptičnih rečenica temelji se na pretpostavkama primatelja o tome koje su informacije izostavljene elipsom, odnosno što je u diskursu antecedent elipse. U navedenim primjerima možemo pretpostaviti kako je Marija samo popila piće, samo otišla kući ili učinila oboje. Odabir određene interpretacije ukazuje na mehanizme sintaktičkog i semantičkog procesiranja te načela kojima je vođen proces razumijevanja. Istraživanjima struktura s mogućnošću višestruke interpretacije nastoji se utvrditi koja su to načela te u kojoj su mjeri ona univerzalna ili uvjetovana strukturom pojedinog jezika.

Cilj ovoga istraživanja jest ispitati kojim se načelima vodi interpretacija elipse $u$ hrvatskome jeziku. Pritom se polazi od pretpostavke da su dominantne strategije odabira antecedenta uvjetovane strukturom diskursa koji prethodi elipsi te će se nakon zavisnosloženih rečenica kao antecedent češće birati glagolska skupina iz glavne rečenice. S druge strane, očekuje se da će na odabir antecedenta iz nezavisnosloženih rečenica u većoj mjeri utjecati redoslijed surečenica, odnosno češće će se birati glagolska skupina linearno bliža mjestu elipse.

U nastavku iznosimo strukturu rada. Budući da se tema elipse u literaturi na hrvatskom jeziku rijetko obrađuje, $u$ drugom se odjeljku daje pregled osnov- 
nih teorijskih pristupa elipsi te obilježja elipse glagolske skupine. U trećem se odjeljku donosi pregled prethodnih psiholingvističkih istraživanja. Provedeni eksperiment povezuje se s istraživanjima usmjerenima na ispitivanje razlika u procesiranju eliptičnih konstrukcija s obzirom na sintaktičku strukturu koja im prethodi. Uz to, istraživanje se dovodi u vezu s odnosom načela hijerarhije i linearnosti u gramatici i procesiranju te se daje pregled istraživanja načela recentnosti u procesiranju neeliptičnih i eliptičnih konstrukcija. Na kraju toga odjeljka prikazuje se istraživanje na koje se ovaj rad u najvećoj mjeri oslanja. Frazier i Clifton (2005), naime, pokazuju kako se elipsa ne procesira na isti način unutar rečenice i nakon rečenične granice. Za procesiranje elipse u diskursu postavljaju te eksperimentalno potvrđuju hipotezu glavne tvrdnje i hipotezu domene koordinacije kojima su u engleskom jeziku vođene strategije odabira antecedenta $\mathrm{u}$ rečenicama s mogućnošću višestruke interpretacije.

U četvrtom se odjeljku postavlja istraživačko pitanje te se iznose hipoteze istraživanja. Očekivanja razlika u procesiranju primjera (1a), (1b) i (1c) temeljena su na dvjema pretpostavkama koje formuliraju Frazier i Clifton (2005). Prema hipotezi glavne tvrdnje novi se jezični materijal povezuje s glavnom tvrdnjom koja je u zavisnosloženoj rečenici sadržana u glavnoj surečenici. Budući da u koordiniranim strukturama glavna tvrdnja nije dostupna jer se ne radi o odnosu glavne i zavisne tvrdnje, novi jezični materijal povezuje se s recentnim materijalom ili s čitavom koordiniranom skupinom u skladu s hipotezom domene koordinacije. U petom odjeljku opisane su metode i postupak kojim je proveden eksperiment. Rezultati ispitivanja iznose se u šestom odjeljku. Pritom se komentiraju zabilježene razlike između eksperimentalnih uvjeta koje potvrđuju kako sintaktička struktura koja prethodi elipsi utječe na njezinu interpretaciju. Kako zaključujemo u sedmom odjeljku, elipsa nakon nezavisnosloženih rečenica interpretirana je u skladu s hipotezom domene koordinacije. Hipoteza glavne tvrdnje potvrđena je češćim odabirom antecedenta iz glavne nego iz zavisnosložene rečenice, no i u tom se slučaju važnim pokazao redoslijed, odnosno načelo recentnosti.

\section{Elipsa}

Kao posljedica redundancije u procesu sporazumijevanja u određenim je kontekstima moguće ispustiti dijelove jezične strukture koji su inače potrebni za 
izražavanje informacije. Dio takvih pojava obuhvaćen je pojmom elipsa krovnim terminom za brojne jezične pojave u kojima u rečenici nedostaje materijal koji je inače obavezan, a elementi koji nedostaju mogu se rekonstruirati iz lokalnog sintaktičkog ili semantičkog konteksta (Phillips i Parker 2014: 78). Uporaba termina elipsa ${ }^{2}$ i fenomeni koji su njime obuhvaćeni uvelike ovise o teorijskom okviru unutar kojega se proučava izostavljanje dijelova jezičnog materijala. U suvremenoj se lingvistici dominantne teorije elipse razvijaju od šezdesetih godina dvadesetog stoljeća u okviru generativne gramatike, pri čemu se opseg uporabe termina sužava na specifične konstrukcije među kojima su najdetaljnije istražene elipsa glagolske skupine ili VP elipsa (engl. verb phrase ellipsis), isprane rečenice ili TP elipsa (engl. sluicing, tense phrase ellipsis), elipsa imenske skupine ili NP elipsa (engl. noun phrase ellipsis) te gapping. ${ }^{3}$

Središnje pitanje u istraživanju eliptičnih konstrukcija jest pitanje generiranja i interpretacije eliptičnih rečenica. Brojne analize u teorijskoj lingvistici prvenstveno su usmjerene na istraživanje elipse iz triju perspektiva. U nastavku navodimo te tri perspektive.

1. Sa stajališta strukturne perspektive postavlja se pitanje postoji li na mjestu elipse neizgovorena sintaktička struktura.

Prema strukturnim teorijama izostavljeni jezični materijal sadrži sintaktičku strukturu na nekoj razini reprezentacije (Ross 1967, Hankamer i Sag 1796, Merchant 2001). Nestrukturne teorije, za razliku od toga, pretpostavljaju kako su u interpretaciju elipse uključeni opći mehanizmi rekonstrukcije značenja iz konteksta (Ginzburg i Sag 2000, Culicover i Jackendoff 2005).

2. Sa stajališta identifikacije s antecedentom postavlja se pitanje o odnosu između elipse i antecedenta. Budući da je elipsa anaforična i njezina interpretacija ovisi o nekom antecedentu, potrebno je odrediti odnos između ta dva segmenta strukture.

S tim u vezi treba reći da su među prvim teorijama sintaktičke identifikacije bile one koje su paralelizam sintaktičke strukture postavljale kao osnovni uvjet za ostvarivanje elipse (Ross 1967, Williams 1977). Te su teorije u posljednjih tridesetak godina uglavnom ustupile mjesto teorijama semantičke identifikacije

\footnotetext{
2 Prvi za kojeg znamo da spominje elipsu jest Izidor Seviljski, koji u svom djelu Podrijetla riječi ili etimologije određuje elipsu kao nepotpunost govora u kojoj nedostaju potrebne riječi.

3 Pregled generativističkoga proučavanja elipse može se naći u Merchant 2016, Winkler i Schwabe 2003.
} 
zasnovanima na uvjetu semantičkog paralelizma između elipse i antecedenta (Hardt 1993, Merchant 2001, Culicover i Jackendoff 2005).

3. Sa stajališta licenciranja elipse postavlja se pitanje koje pozicije ili strukture dopuštaju elipsu i pod kojim uvjetima.

Pitanje licenciranja odnosi se na razumijevanje distribucije elipse. Utvrđeno je kako različiti jezici imaju različite mogućnosti ispuštanja jezičnog materijala. Dok su neke eliptične konstrukcije, primjerice isprane rečenice, prisutne u brojnim jezicima, elipsa glagolske skupine kao posebni oblik elipse predikata, znatno je rjeđa. Uz to, uvjeti ostvarivanja i interpretacije određenog tipa elipse ne podudaraju se u svim jezicima u kojima se određena konstrukcija može pronaći. Kako ti uvjeti nisu analitički dovoljno razrađeni, ovaj je rad prilog upravo tom dijelu razumijevanja funkcioniranja elipse glagolske skupine.

Uz sve navedeno, u suvremenoj je lingvistici, osobito u posljednjih tridesetak godina, prepoznata i važnost informacijske strukture koja je, uz sintaktičku i semantičku razinu, nužna za opis i razumijevanje eliptičnih pojava (Rooth 1992, Merchant 2001, Kertz 2013). Ta se istraživanja osobito tiču ograničenja koja utječu na prihvatljivost eliptičnih rečenica, čega ćemo se također dotaknuti u nastavku rada.

\subsection{Elipsa glagolske skupine ili VP elipsa u hrvatskom jeziku}

Elipsu glagolske skupine ili VP elipsu moguće je odrediti kao sintaktičku konstrukciju u kojoj nedostaje surečenični predikat, obično zajedno sa svojim unutarnjim argumentima (van Craenenbroeck 2017: 1). Primjer koji se s tim u vezi najčešće navodi u literaturi jest:

(2) John is sleeping, and Bill is [ ] too. ${ }^{4}$

Takve su konstrukcije primarno uočene i analizirane u engleskom jeziku, ponajprije u okviru generativne gramatike (Ross 1967, Hankamer i Sag 1976,

\footnotetext{
${ }^{4}$ Svi će engleski primjeri biti prevedeni u fusnotama zbog potpunijega razumijevanja. Kako su primjeri jezičnospecifični, neki će prijevodi rezultirati negramatičnim rečenicama u hrvatskom.

Prijevod: Ivan spava i Bill isto [ ].
} 
Williams 1977, Lobeck 1995, Hardt 1993, Johnson 2001). Termin elipsa glagolske skupine u literaturi je poznat od sedamdesetih godina dvadesetog stoljeća kada se $\mathrm{u}$ generativnoj sintaksi kao jedina funkcionalna projekcija povezana $\mathrm{s}$ glagolom pretpostavljala glagolska skupina. Porast broja funkcionalnih projekcija glagolske domene dovodi do novih analiza elipse glagolske skupine prema kojima se u takvom tipu elipse ne izostavlja isključivo glagolska skupina (Aelbrecht i Harwood 2013, Merchant 2013, Bošković 2014). S obzirom na to da se u linearnoj strukturi takav tip elipse detektira prema mjestu elipse smještenom nakon pomoćnog glagola, termin elipsa nakon pomoćnog glagola (engl. post-auxiliary ellipsis) bolje odgovara konstrukcijama poput one u primjeru (2). Taj termin predlaže već Sag (1976), a kasnije ga prihvaćaju i Miller i Pullum (2012). Kako su istraživanja u drugim jezicima pokazala da pomoćni glagol nije uvijek nužan u takvim konstrukcijama, termin elipsa glagolske skupine do danas je ostao pretežit u najvećem dijelu literature. Stoga ćemo ga i mi koristiti u ovom radu.

Iako se u literaturi navode primjeri elipse glagolske skupine u srednjojužnoslavenskom kompleksu (Stjepanović 1998, Willer-Gold 2013, Bošković 2014), mogućnosti i ograničenja njezina ostvarivanja u hrvatskom jeziku nisu detaljno istraženi. U nastavku se iznose neka obilježja elipse glagolske skupine u hrvatskom koja su se pokazala relevantnima za odabir eksperimentalnog materijala.

Kao prvo, s obzirom na pitanje identifikacije elipsa glagolske skupine u hrvatskom jeziku ne mora biti morfosintaktički identična antecedentu, nego se od njega može razlikovati u rodu, pa čak i broju:

(3) a. Marko je pročitao knjigu, a Ivana nije [pročitala knjigu].

b. Marko je pročitao knjigu, a njegovi prijatelji nisu [pročitali knjigu].

S obzirom na distribuciju elipsa glagolske skupine može biti u istoj rečenici kao i antecedent, ali ne mora. Primjer su prvog slučaja netom navedene rečenice, a primjer drugog rečenica koja slijedi:

(4) Marko je pročitao knjigu. Nažalost, Ivana nije. [pročitala knjigu].

Uz to, u hrvatskom su mogući i podijeljeni antecedenti (engl. split antecedents): 
(5) Ivana je htjela ići u Englesku, a Marko u Francusku, ali nisu. [išli ni u Englesku ni u Francusku $]^{5}$

Uz sve navedeno, u hrvatskom je gramatički prihvatljiva i elipsa koja otvara mogućnost višestruke interpretacije: ${ }^{6}$

(6) Marko je pročitao knjigu i pojeo sendvič. I Josip je. [pročitao knjigu]

[pojeo sendvič]

[pročitao knjigu i pojeo sendvič]

U ovom se radu, kao što je već najavljeno, ispituju strategije odabira antecedenta eliptičnih rečenica poput onih u primjeru (6).

\section{Pregled psiholingvističkih istraživanja}

\subsection{Procesiranje elipse}

Brojna psiholingvistička istraživanja elipse usmjerena su na eksperimentalno ispitivanje teorijskih postavki o postojanju strukture na mjestu elipse i prirodi antecedenta te ograničenja u njezinu ostvarivanju. Među tim istraživanjima prednjače studije o utjecaju složenosti antecedenta na brzinu i točnost interpretacije elipse glagolske skupine te ispitivanja sintaktički nepodudarnih antecedenata i pretpostavljenih interpretacija na mjestu elipse. Rezultati istraživanja utjecaja složenosti antecedentata provedena različitim metodama (Murphy 1985, Martin i McElree 2008) ne podudaraju se, što može biti posljedica različitih metodologija ili drugih razloga, dok su se $u$ ispitivanjima sintaktički nepodudarnih antecedenata pokazale sustavne razlike u prihvatljivosti eliptičnih konstrukcija s obzirom na tip kršenja sintaktičkih ograničenja (Arregui i dr. 2006, Kim i dr. 2011).

\footnotetext{
5 Zahvaljujemo anonimnom recenzentu ili recenzentici na upozorenju vezanom uz ovaj tip rečenice. Takva interpretacija nije eksperimentalno potvrđena, no ispitivanjem među govornicima hrvatskog jezika utvrdile smo sintaktičku i semantičku prihvatljivost takvoga tumačenja.

6 Taj je tip elipse posebno zanimljiv zato što se, dakako, uz pitanje procesiranja, postavlja pitanje o tome o kojim se sve sintaktičkim strukturama radi u podlozi takvih rečenica.
} 
Eksperimentalnim se istraživanjima dodatno pokazalo kako na razlike u prihvatljivosti i vremenu procesiranja elipse glagolske skupine utječe i struktura sintaktičkih odnosa preslikanih na strukturu diskursa. Shapiro i Hestvik (1995) u eksperimentu provedenom uz korištenje zadataka multimodalnoga prajmiranja (engl. cross-modal lexical priming task) pokazali su kako se elipsa glagolske skupine $u$ engleskom različito procesira u subordiniranim i koordiniranim strukturama, što je posebno značajno za temu ovog rada. Ispitanicima su tijekom rješavanja zadataka leksičke odluke prikazanih u pisanom obliku (na računalu) auditivno prezentirane eliptične rečenice, dok se zadatak leksičke odluke na ekranu prikazivao u tri uvjeta: (1) prije mjesta elipse, (2) na mjestu elipse i (3) nakon mjesta elipse. Pokazalo se da su ispitanici prilikom procesiranja nezavisnosloženih eliptičnih rečenica pristupili antecedentu na samom mjestu elipse, dok su u primjerima sa zavisnosloženim rečenicama pristupali antecedentu tek nakon mjesta elipse. Autori tvrde da takvi rezultati upućuju na automatsku interpretaciju elipse u koordiniranim strukturama, za razliku od subordiniranih, gdje prvo dolazi do razumijevanja odnosa među surečenicama.

Nastavno na to, Garnham i dr. (1998) uočili su razlike u procesiranju elipse glagolske skupine u zavisnosloženim rečenicama s obzirom na surečenicu koja sadrži antecedent. Oni su utvrdili kako je za procjenu prihvatljivosti elipse glagolske skupine potrebno kraće vrijeme ako je pretpostavljeni antecedent u zavisnoj surečenici nego ako je u glavnoj, neovisno o njihovu redoslijedu. Premda je u istom istraživanju uočen i efekt recentnosti na procesiranje elipse otprije poznat iz sintaktičke literature i testiran na drugim tipovima struktura, treba istaknuti kako se efekt kraćeg procesiranja elipse glagolske skupine pokazao u oba uvjeta, i kad je zavisnosložena rečenica bila linearno prva i kad je bila linearno druga. ${ }^{7}$

Opisana istraživanja usmjerena su na ispitivanje procesiranja elipse glagolske skupine s jednim mogućim antecedentom. Međutim, kao što će biti prikazano u nastavku, efekt recentnosti kao obilježje obrade unutar jedne rečenice ${ }^{8}$ istraživan je i s obzirom na razumijevanje struktura s mogućnošću višestruke interpretacije.

7 Kad se uzme u obzir činjenica da je zavisnosložena surečenica, u poziciji u kojoj se nalazi ispred glavne surečenice, informacijskih istaknuta, jasno je da informacijska struktura u takvoj analizi mora igrati ulogu, posebno efekt fokusiranja.

8 Frazier i Clifton (2005) taj tip obrade nazivaju obilježjem sintaktičkog procesiranja, za razliku od diskurzivnog procesiranja koje prelazi rečeničnu granicu. 


\subsection{Sintaktičko procesiranje: načelo recentnosti}

Gibson (1991, 1998) te Pearlmutter i Gibson (2001) tvrde da osnovnim načelom sintaktičke obrade treba smatrati načelo recentnosti, dok su sva ostala u literaturi spomenuta načela, kao načelo desnog povezivanja (Kimball 1973), načelo lokalnosti, odnosno kasnog zatvaranja (Frazier i Fodor 1978, Frazier 1979) samo teorijske konstrukcije kojima se tumače detalji primjene toga osnovnoga načela. Prema načelu recentnosti strukture koje slijede povezuju se s materijalom koji se nedavno pojavio u rečenici (Gibson 1991). Tako se tvrdi da se u primjeru koji navodi Kimball (1973):

(7) Bill thought John died yesterday. ${ }^{9}$

prilog yesterday može vezati uz glagol u glavnoj surečenici, no ipak se znatno češće vezuje uz glagol zavisne surečenice (Gibson 1991).

Istraživanja utjecaja recentnosti na sintaktičku obradu prvenstveno su usmjerena na ispitivanje odabira antecedenta relativnih rečenica. Psiholingvistička istraživanja provedena na engleskom jeziku pokazuju da u rečenicama koje otvaraju mogućnost višestrukih interpretacija govornici redovito vežu relativnu surečenicu uz linearno bližu imenicu, kao na primjer u Cuetos i Mitchell (1988):

(8) Someone shot the female servant of the actress who was on the balcony. ${ }^{10}$

Međutim, istraživanja u brojnim drugim jezicima pokazuju kako načelo recentnosti u odabiru antecedenta višeznačne relativne rečenice nije univerzalno, nego vezanje relativne rečenice ovisi o strukturi jezika te obilježjima istraživanih sintaktičkih struktura. Za hrvatski je jezik uočen efekt duljine relativne surečenice pa tako Lovrić i Fodor $(2000)^{11}$ tvrde da se kraće relativne surečenice češće vezuju uz linearno bližu imenicu u složenoj imenskoj skupini nego što je to slučaj s duljim relativnim surečenicama. Na recentnost, odnosno vezivanje relativnih surečenica u hrvatskom jeziku prema hijerarhijskom ili linearnom načelu, utječe i tip složene imenske skupine unutar koje se odabire antecedent. U prethodnim

\footnotetext{
9 Prijevod: Bill je mislio da je John umro jučer.

${ }_{10}$ Prijevod: Netko je upucao služavku glumice koja je bila na balkonu.

${ }^{11}$ Lovrić i Fodor (2000) efekt duljine pripisuju utjecaju prozodijskih obilježja na jezično procesiranje.
} 
se istraživanjima slaganja s koordiniranom skupinom (Willer-Gold i dr. 2016, 2018, Matić i dr. 2019) pokazalo da redoslijed igra ulogu u gramatičkom slaganju u rodu, broju i padežu takvih struktura. U tim se istraživanjima uz slaganje s čitavom koordiniranom strukturom pokazao i znatan broj slaganja s bližim konjunktom. ${ }^{12}$

\subsection{Procesiranje elipse u diskursu}

Iz psiholingvističke je literature poznato kako obrada jedinica većih od razine rečenice nije uvijek vođena istim načelima kao i obrada unutar jedne rečenice. Već su rana psiholingvistička istraživanja jezičnog procesiranja pokazala kako se sintaktička struktura, za razliku od značenja iskaza, vrlo kratko zadržava u pamćenju, osobito nakon rečenične granice (Caplan 1972, Jarvella 1971). Frazier i Clifton (2005) polaze od pretpostavke da se nakon rečenične granice mijenja dostupnost sintaktičke reprezentacije u odnosu na reprezentaciju diskursa. Ta je pretpostavka ispitana upravo na primjeru elipse glagolske skupine koja otvara mogućnost višestruke interpretacije:

(9) a. John said that Fred went to Europe and Mary did too.

b. John said that Fred went to Europe. Mary did too. ${ }^{13}$

Ispitanici češće biraju linearno bližu glagolsku skupinu kao antecedenta elipse u primjeru (9a), što je u skladu s rezultatima istraživanja strategija vezanja višeznačnih relativnih surečenica u engleskom jeziku. S druge strane, u primjerima poput (9b) dominantna je interpretacija prema kojoj je antecedent glagolska skupina glavne rečenice. Odabir upravo tog antecedenta u dvorečeničnom diskursu Frazier i Clifton (2005) pripisuju važnosti informacijske strukture za reprezentaciju diskursa te primateljevim očekivanjima o tome da se najvažnije informacije nalaze u glavnoj surečenici. Pozivajući se na teoriju centriranja i istraživanja preferiranog antecedenta ličnih zamjenica prema kojima se antecedent odabire

\footnotetext{
${ }^{12}$ Detaljan pregled psiholingvističkih istraživanja strategija vezanja relativnih surečenica donosi se u Matić i dr. 2019.

13 Prijevod: a. John je rekao da je Fred otišao u Europu i Mary je također.

b. John je rekao da je Fred otišao u Europu. Mary je također.
} 
iz glavne tvrdnje (Gordon i Hendrick 1998, Grosz, Joshi i Weinstein 1995), Frazier i Clifton $(2005: 127,139)$ formuliraju dvije hipoteze relevantne za tumačenje elipse, hipotezu glavne tvrdnje i hipotezu domene koordinacije:

(i.) Hipoteza glavne tvrdnje:

Novi jezični materijal povezuje se s glavnom tvrdnjom prethodne rečenice ako je ona lako dostupna.

Hipoteza glavne tvrdnje eksperimentalno je potvrđena u engleskom jeziku ispitivanjem odabira antecedenta elipse glagolske skupine s mogućnošću višestruke interpretacije u dvorečeničnim diskursima (Frazier i Clifton 2005: 147):

(10) a. Sam sat down after he introduced himself. Then Fred did.

b. After Sam sat down he introduced himself. Then Fred did. ${ }^{14}$

Did se češće interpretira kao sat dow kada je ta glagolska skupina dio glavne surečenice (10a). S druge strane, kad eliptična rečenica dolazi nakon nezavisnosložene rečenice te se ne može odrediti lako dostupna glavna tvrdnja, rezultati ispitivanja odabira antecedenta u skladu su s hipotezom domene koordinacije (Frazier i Clifton 2005: 127):

(ii.) Hipoteza domene koordinacije:

U obradi koordinirane strukture dostupna je čitava koordinirana struktura ili samo recentna sastavnica, no ne i linearno najudaljenija sastavnica koordinacije.

Utjecaj recentnosti na interpretaciju elipse nakon koordinirane strukture eksperimentalno je potvrđen ispitivanjem procesiranja dvorečeničnih diskursa poput sljedećeg primjera (Frazier i Clifton 2005):

(11) a. Sam sat down and he was unhappy. Then Fred did.

b. Sam was unhappy and he sat down. Then Fred did. ${ }^{15}$

\footnotetext{
${ }^{14}$ Prijevod: a. Sam je sjeo nakon što se predstavio. Onda je i Fred.

b. Nakon što je Sam sjeo, predstavio se. Onda je i Fred.

${ }^{15}$ Prijevod: a. Sam je sjeo i bio je nesretan. Onda je i Fred.

b. Sam je bio nesretan i sjeo je. Onda je i Fred.
} 
U primjeru (11a) odgovarajući antecedent elipse udaljenija je glagolska skupina, dok je u primjeru (11b) odgovarajući antecedent bliža, odnosno recentna glagolska skupina. U zadatku čitanja vlastitom brzinom (engl. self-paced reading task) zabilježene su poteškoće u procesiranju primjera poput (11a) u kojima recentna glagolska skupina nije bila odgovarajući antecedent.

\section{Istraživačko pitanje i pretpostavke istraživanja}

Kao što je dosada izneseno, rezultati dosadašnjih psiholingvističkih istraživanja ukazuju na:

1) utjecaj recentnosti na obradu unutar jedne rečenice, uključujući procesiranje elipse glagolske skupine $\mathrm{s}$ jednim mogućim antecedentom i višeznačne elipse glagolske skupine u engleskom jeziku, kao i utjecaj recentnosti na obradu koordiniranih skupina u relativnim rečenicama u hrvatskom jeziku

2) utjecaj sintaktičke strukture koja prethodi mjestu elipse glagolske skupine na brzinu procjene prihvatljivosti elipse unutar jedne rečenice

3) razlike u interpretaciji elipse s mogućnošću višestruke interpretacije unutar jedne rečenice i nakon rečenične granice

4) utjecaj sintaktičke strukture prethodne rečenice na interpretaciju elipse glagolske skupine s mogućnošću višestruke interpretacije.

U ovom se radu, na temelju dosadašnjih istraživanja u engleskom i hrvatskom, ispituju strategije odabira antecedenta elipse glagolske skupine koja otvara mogućnost višestruke interpretacije u hrvatskom jeziku. S tim se u vezi postavlja osnovno istraživačko pitanje koje glasi: Na koji način struktura koja prethodi eliptičnoj rečenici uvjetuje dominantne strategije odabira antecedenta elipse?

U ovom radu ponajprije polazimo od prikazanih istraživanja koja odnos hijerarhije i linearnosti u procesiranju ispituju upravo na eliptičnim konstrukcijama u strukturama koje prekoračuju razinu rečenice. Činimo to usuprot dosadašnjim malobrojnim eksperimentalnim bavljenjima relativnim rečenicama u hrvatskom jeziku u kojima se nije pokazala potpuna podudarnost preferencija vezanja $\mathrm{s}$ onom u engleskom, zato što se u tim radovima radilo o istraživanjima sintaktič- 
koga slaganja, i to mahom unutar jedne rečenice, a ne o istraživanjima procesiranja i odabira antecedenata u strukturama koje prekoračuju rečeničnu granicu. S obzirom na to da istražujemo elipsu glagolske skupine s mogućnošću višestruke interpretacije u dvorečeničnom diskursu, hipoteze koje predlažemo oslanjaju se na prethodna istraživanja upravo takvih konstrukcija:

1. Hipoteza glavne tvrdnje u hrvatskome će biti potvrđena u elipsi koja slijedi nakon zavisnosloženih rečenica neovisno o redoslijedu surečenica.

2. Hipoteza domene koordinacije u hrvatskome će biti potvrđena u elipsi koja slijedi nakon nezavisnosloženih rečenica.

Takva očekivanja proizlaze iz teorijske i eksperimentalne podloge koju su postavili Frazier i Clifton (2005), a u raspravi nakon prikaza rezultata podaci ovoga istraživanja bit će stavljeni u kontekst drugih istraživanja suodnosa hijerarhijskoga i linearnog načela u hrvatskome.

\section{Metode}

\subsection{Sudionici}

U istraživanju provedenom u okviru projekta HRZZ-a Modeliranje mentalne gramatike hrvatskoga: ograničenje informacijske strukture uz dopuštenje Etičkoga povjerenstva Filozofskog fakulteta sudjelovale su 32 osobe, studenti i studentice Filozofskog fakulteta Sveučilišta u Zagrebu. Svi su sudionici izvorni govornici hrvatskoga jezika, uredna jezičnoga statusa, bez povijesti neuroloških oštećenja i razvojnih odstupanja te neoštećena ili korigirana vida. Socioekonomski status nije kontroliran. Svi su sudionici prethodno upoznati s postupkom i predviđenim trajanjem ispitivanja te su potpisali suglasnost za sudjelovanje i ispunili kratki demografsko-sociolingvistički upitnik. Zajamčena im je anonimnost, a u svakom su se trenutku mogli povući iz ispitivanja bez obveze navođenja razloga povlačenja. Ispitanici su nakon sudjelovanja upoznati sa svrhom istraživanja te su dobili odgovore na eventualna pitanja. Ostali podaci o sudionicima (spol i dob) prikazani su u Tablici 1. 
Tablica 1. Opis uzorka $(N=32)$

SPOL

M $\check{Z}$

$14 \quad 18$
DOB

Prosječna dob Min. Maks.

$22,5 \quad 20$

29

\subsection{Materijali i dizajn eksperimenta}

U istraživanju je korišten jednostavan zavisni eksperimentalni nacrt $\mathrm{s}$ jednom nezavisnom varijablom - vrstom neeliptične rečenice. Ta je varijabla imala tri razine: (1) subordinirana struktura (zavisnosložena rečenica) u kojoj je prva surečenica glavna, a druga zavisna $(\mathrm{S}, \mathrm{G}-\mathrm{Z}$ ), (2) subordinirana struktura (zavisnosložena rečenica) u kojoj je prva surečenica zavisna, a druga je glavna (S, Z - G) i (3) kooridinirana struktura (nezavisnosložena rečenica, K). Eksperimentalni uvjeti odgovarali su razinama nezavisne varijable.

Preferencije govornika ispitane su zadatkom razumijevanja s ponuđenim odgovorima. Cilj eksperimenta bio je utvrditi koje će odgovore sudionici najčešće odabrati u kojem uvjetu. Redoslijedom surečenica ispitivao se utjecaj recentnosti na odabir antecedenta elipse, dok se tipom surečenice zavisnosloženih rečenica ispitivao utjecaj glavne tvrdnje na odabir antecedenta.

Tablica 2 prikazuje eksperimentalne uvjete s primjerima. S obzirom na to da je u trećem uvjetu variran redoslijed sastavnica u koordiniranoj skupini, primjeri su prikazani kao 3 a i $3 b$.

Tablica 2. Eksperimentalni uvjeti i primjeri stimulusa

\section{Eksperimentalni uvjeti i primjeri}

(1) $S, G-Z$ Robi je otvorio restoran nakon što je prodao vikendicu. I Nikola je.

(2) $\mathrm{S}, \mathrm{Z}-\mathrm{G}$ Nakon što je prodao vikendicu, Robi je otvorio restoran. I Nikola je.

(3a) $\mathrm{K} \quad$ Robi je otvorio restoran i prodao vikendicu. I Nikola je.

(3b) K Robi je prodao vikendicu i otvorio restoran. I Nikola je. 


\section{Tipovi umetnutih stimulusa i primjeri}

S(P) Prije nego što su djedovi i bake otišle, Monika se jako naljutila. Janica je došla prije nego što su se igrači i sutkinje posvađali.

K(P) Dječaci i djevojčice su se zabavljale, a Kristina je plakala.

Ljiljana je organizirala radionicu, a volonteri i volonterke su pripremili materijale.

Osmišljeno je 40 dvorečeničnih diskursa sastavljenih od jedne neeliptične i jedne eliptične rečenice koji su potom oblikovani kako bi odgovarali pojedinom eksperimentalnom uvjetu kao što je prikazano na primjeru u Tablici 2. Time je smanjena mogućnost da se dobivene razlike u odgovorima sudionika pripišu sadržaju rečenica, a ne samo njihovoj strukturi.

Formirane su četiri verzije liste stimulusa u kojima je svaki od odgovarajućih stimulusa prikazan u samo jednom obliku. Sudionicima je po slučaju dodijeljena jedna od četiri verzije liste, a u konačnici je kroz svaku verziju liste prošao jednak broj sudionika. Na razini sudionika svaki je odgovorio na 40 eksperimentalnih stimulusa, od čega su 20 činile nezavisnosložene rečenice, a $20 \mathrm{su}$ bile zavisnoložene, od kojih je kod 10 glavna rečenica bila prva, a kod 10 glavna rečenica bila je druga po redu.

Svi su eksperimentalni stimulusi ujednačeni prema sljedećim kriterijima:

1. rečenice su uvijek bile u perfektu

2. subjekti rečenica uvijek su bila osobna imena.

Sve su nezavisnosložene rečenice bile sastavne rečenice s veznikom $i$, dok su sve zavisnosložene rečenice bile vremenske s veznikom nakon što.

Eliptična rečenica uvijek je imala oblik 'I X je.' kako bi se osiguralo da na rezultate ne utječu razlike u strukturi same eliptične rečenice. Budući da elipsa glagolske skupine u hrvatskom jeziku do sada nije eksperimentalno ispitivana, $\mathrm{u}$ ovom istraživanju polazimo od minimalne strukture s kanonskim redoslijedom subjekta i (dijela) predikata te mjestom elipse na kraju rečenice. Eventualne razlike u interpretaciji elipse uvjetovane strukturom i duljinom eliptične rečenice ostavljamo za buduća istraživanja. 
Kako ispitanici ne bi lako prepoznali svrhu ispitivanja te kako bi se pratilo čitaju li s razumijevanjem, smišljeno je i 40 umetnutih stimulusa koji su bili jednaki u svim verzijama liste. Svi su umetnuti stimulusi ujednačeni prema sljedećim kriterijima:

1. sastojali su se od jedne složene rečenice u perfektu

2. u svakom se stimulusu nalazila koordinirana struktura sastavljena od imenice ženskog i muškog roda.

Tako strukturirani umetnuti stimulusi dalje su razdijeljeni u dvije skupine. Polovicu umetnutih stimulusa činile su nezavisnosložene suprotne rečenice s veznikom $a$, a drugu polovicu zavisnosložene vremenske rečenice s veznikom prije nego što, od kojih je 10 započinjalo glavnom, a 10 zavisnom surečenicom. U polovici umetnutih stimulusa glagol se slagao s koordiniranom sastavnicom $\mathrm{u}$ ženskom rodu, a u drugoj polovici sa sastavnicom u muškom rodu.

Nakon svakog stimulusa slijedilo je isto pitanje: „Što se dogodilo s X?” te su bila ponuđena tri odgovora. Za eksperimentalne stimuluse prvi se odgovor uvijek sastojao od glagolske skupine linearno udaljenije od mjesta elipse, tj. prve po redoslijedu. Za primjer Robi je otvorio restoran nakon što je prodao vikendicu. I Nikola je., koji je prikazan u Tablici 2, prvi ponuđeni odgovor glasio je: Otvorio je restoran. Drugi odgovor uvijek se sastojao od glagolske skupine linearno bliže mjestu elipse, tj. druge po redoslijedu (Prodao je vikendicu.), dok je treći ponuđeni odgovor sadržavao koordinaciju sastavljenu od glagolskih skupina iz prve rečenice stimulusa (Otvorio je restoran i prodao vikendicu.).

Budući da je u uvjetu u kojem eliptičnoj rečenici prethodi nezavisnosložena rečenica koordinirana struktura prisutna i u stimulusu i u trećem ponuđenom odgovoru, dok je u prvim dvama uvjetima sintaktička struktura odgovora promijenjena u odnosu na stimulus te je zavisnosloženi odnos zamijenjen koordiniranim, materijali u tom pogledu nisu u potpunosti ujednačeni. Koordiniranu strukturu kao ponuđeni odgovor i nakon zavisnosložene rečenice smatramo opravdanim zbog usporedivosti sadržaja tih dviju struktura (otvorio restoran nakon što je prodao vikendicu i otvorio restoran i prodao vikendicu). Uz to, na taj je način ujednačena sintaktička složenost ponuđenih odgovora u svim uvjetima. 
Redoslijed odgovora nakon umetnutih stimulusa bio je jednak kao i za eksperimentalne stimuluse, no samo je jedan odgovor bio točan. Budući da su se rečenice sintaktički razlikovale, točan odgovor nije uvijek bio pod istim rednim brojem.

\subsection{Postupak}

Ispitivanje je provedeno individualno u prostorijama Filozofskog fakulteta $\mathrm{u}$ Zagrebu, a sudionicima su stimulusi prikazivani na računalu pomoću računalnog programa E-Prime 2.0 (Schneider i dr. 2002) pri čemu su bilježeni njihovi odgovori i vrijeme reakcije. Vrijeme reakcije mjereno je od početka prikaza ponuđenih odgovora, odnosno nakon čitanja stimulusa. Budući da se prilikom istraživanja oblikovanog na opisani način ne može jasno razlučiti ukazuje li produljeno vrijeme reakcije na poteškoće u procesiranju ili na dulji proces donošenja odluke, a ni duljina odgovora nije bila u potpunosti ujednačena u svim primjerima, što je moglo utjecati na rezultate, vrijeme reakcije korišteno je samo kao dodatna informativna mjera.

Sudjelovanje u istraživanju bilo je dobrovoljno. Prije samoga ispitivanja predstavljen je opći cilj istraživanja te su sudionici ispunili tiskani demografsko-sociolingvistički upitnik i pristanak za sudjelovanje. Upute u upitniku bile su jednostavne. Sudionici su zamoljeni da pažljivo pročitaju prikazane rečenice te pritisnu razmaknicu na računalu, nakon čega je slijedilo pitanje s tri ponuđena odgovora. Sudionici su upućeni na to da pritiskom odgovarajuće tipke na računalu odaberu onaj odgovor za koji smatraju da najbolje odgovara značenju rečenica koje su pročitali. Rečeno im je kako će se pratiti i brzina reakcije od trenutka prikazivanja pitanja s ponuđenim odgovorima. Svakom je sudioniku prikazano ukupno 80 podražaja: po 10 za prva dva uvjeta, 20 za treći uvjet te 40 umetnutih stimulusa. Stimulusi su prikazivani u slučajnom redoslijedu. Ispitivanje je trajalo oko 25 minuta. Primjer postupka prikazan je u nastavku:

(Na ekranu se prikazuje stimulus.)

Robi je otvorio restoran nakon što je prodao vikendicu. I Nikola je.

(Pritiskom razmaknice stimulus nestaje te se na ekranu pojavljuje pitanje s tri ponuđena odgovora.) 
Što se dogodilo s Nikolom?

1) Otvorio je restoran.

2) Prodao je vikendicu.

3) Otvorio je restoran i prodao vikendicu.

(Pritiskom odgovarajuće tipke tekst nestaje s ekrana te se nakon kratke stanke pojavljuje novi stimulus.)

\section{Rezultati i rasprava}

Za svakog sudionika izračunat je broj odabira svake vrste odgovora u svakom od eksperimentalnih uvjeta. S obzirom na to da je u trećem eksperimentalnom uvjetu, u kojem je neeliptična rečenica bila nezavisnosložena koordinirana struktura, bilo po 20 primjera, a u ostalim eksperimentalnim uvjetima po 10 , rezultati sudionika izraženi su kao postotak odabira svake vrste odgovora u svakom od eksperimentalnih uvjeta. Rezultati su prikazani na Slici 1. Dodatna statistička analiza podataka izvršena je programom SPSS 23.0.

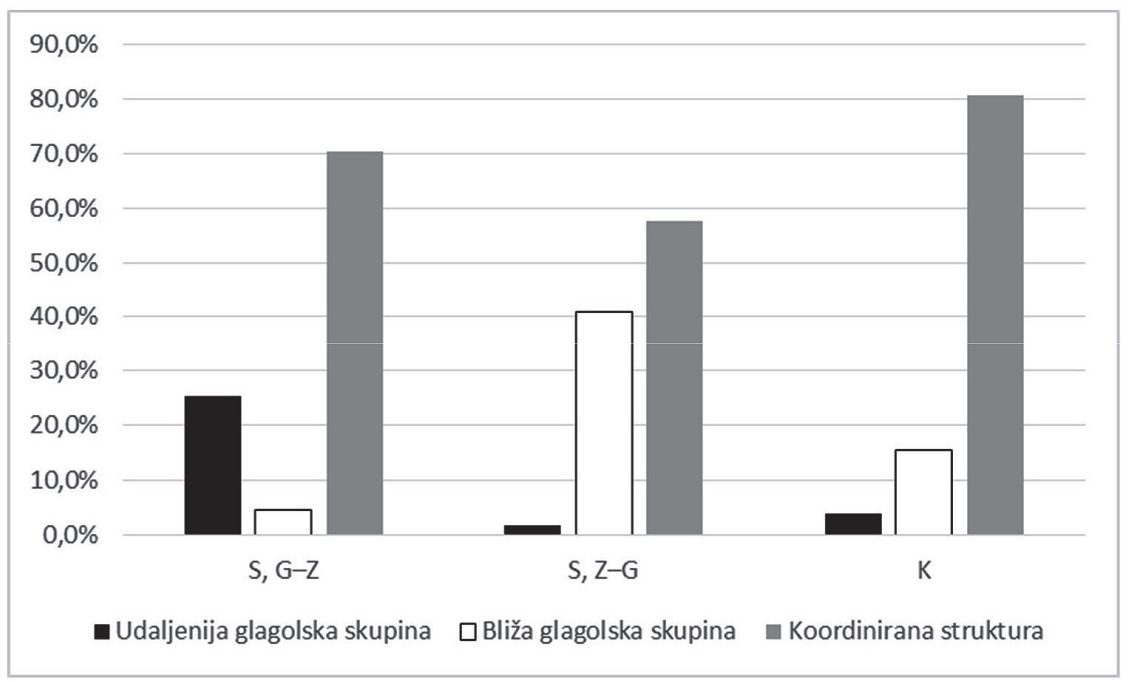

Slika 1. Prosječni postotci (aritmetičke sredine) odabira antecedenta elipse u različitim eksperimentalnim uvjetima. 
Rezultati ispitivanja odabira antecedenta elipse glagolske skupine koja otvara mogućnost višestruke interpretacije pokazuju kako sintaktička struktura prethodne rečenice utječe na strategiju odabira antecedenta. Naime, iako je u svim trima uvjetima u najvećem broju slučajeva kao antecedent elipse birana čitava koordinirana skupina, vidljivi su efekti glavne tvrdnje i recentnosti

Kao što se vidi na Slici 1, u prvom uvjetu, u kojem je eliptičnoj rečenici prethodila zavisnosložena rečenica s redoslijedom surečenica glavna - zavisna, prosječan postotak odabira čitave koordinirane strukture najviši je (70,3 \%), slijedi glagolska skupina iz glavne surečenice, udaljenija od mjesta elipse ( $25 \%$ ), dok je glagolska skupina bliža mjestu elipse u prosjeku birana samo u 4,4 \% slučajeva. Dok odabir čitave koordinirane skupine nije bio predviđen hipotezama te ukazuje na to da se prilikom tumačenja elipse ne radi o sintaktičkoj, nego primarno o semantičkoj identifikaciji zasnovanoj na uvjetu semantičkoga paralelizma između elipse i antecedenta o kojima smo već govorile, razlika između odabira udaljenije i bliže glagolske skupine u skladu je s hipotezom glavne tvrdnje. Kako je u ovom slučaju glavna tvrdnja prva, udaljenija od elipse same, a ipak je odabrana znatno više puta nego bliža tvrdnja, to je jasan znak njezine relevantnosti.

U drugom uvjetu, u kojem je eliptičnoj rečenici prethodila zavisnosložena rečenica s redoslijedom zavisna - glavna, čitava koordinirana struktura birana je u prosjeku u 57,5 \% slučajeva, bliža glagolska skupina u 40,9 \% slučajeva, dok je u najmanjem postotku odabrana udaljenija glagolska skupina koja nije bila dio glavne tvrdnje (1,6 \%). Budući da je razlika između odabira udaljenije i bliže glagolske skupine znatna, i taj rezultat ukazuje na istaknutost glavne tvrdnje u procesiranju. Uz to, razlika između postotka odabira glavne surečenice kad je ona prva ili druga, dakle udaljenija ili bliža mjestu elipse (40,9 \% naspram $25 \%$ ), usmjerava pažnju prema relevantnosti recentnosti. Ta je razlika u prosječnom broju odabira odgovora glagolske skupine glavne surečenice u uvjetima kada je ona bila prva ili druga po redu testirana t-testom za zavisne uzorke koji je pokazao da se radi o statistički značajnoj razlici $(t(31)=3,69 ; p<0,01$; Cohenov $d=0,65)$. Iako je na temelju eksperimenta u engleskom jeziku predviđeno kako redoslijed surečenica u zavisnosloženim rečenicama neće utjecati na odabir antecedenta, rezultati našega ispitivanja ukazuju na znatan utjecaj recentnosti u hrvatskome. Dodatno smo na isti način usporedile prosječan broj odabira odgovora glagolske skupine zavisne surečenice u uvjetu kada je ona bila prva $(1,6 \%)$ i u uvjetu kada je ona 
bila druga $(4,4 \%)$ koji je pokazao statistički značajnu razliku $(t(31)=2,18 ; p<$ 0,05 ; Cohenov $d=0,39$ ). Ti rezultati dodatno potvrđuju ulogu recentnosti čak i u slučaju zavisnih rečenica koje su, premda iznimno rijetko birane kao antecedent, ipak značajno češće birane kad su bile bliže mjestu elipse.

U trećem uvjetu, u kojem je eliptičnoj rečenici prethodila nezavisnosložena sastavna rečenica, kao antecedent elipse najčešće je u prosjeku birana čitava koordinirana struktura $(80,8 \%)$, potom bliža glagolska skupina $(15,3 \%)$ te $\mathrm{u}$ najmanjem broju slučajeva udaljenija glagolska skupina (3,9 \%). Kako je riječ o strukturi u kojoj ne postoji sintaktička hijerarhija uvjetovanosti između dviju surečenica, nego samo linearni redoslijed, a budući da hipoteza domene koordinacije ne predviđa razlike u odabiru bližeg konjunkta i čitave koordinirane strukture, dobivenom razlikom između odabira udaljenije i bliže glagolske skupine te udaljenije glagolske skupine i koordinirane strukture, ta je hipoteza potvrđena. Činjenicu da je čitava koordinirana struktura birana u znatno višem postotku nego recentna glagolska skupina, kad ih se usporedi s rezultatima dosadašnjih ispitivanja slaganja s koordiniranom strukturom (Willer-Gold i dr. 2016, 2018) i ispitivanja relativnih rečenica (Matić i dr. 2019) u hrvatskom, zasad se može tumačiti samo iz perspektive ponuđenih odgovora. Naime, odgovor u kojem je ponuđeno i jedno i drugo, koji je najčešće biran, predstavlja siguran put koji je upravo stoga vjerojatno birala većina ispitanika. Nadopuna ovom eksperimentu u istraživanju tumačenja elipse glagolske skupine koja otvara mogućnost višestruke interpretacije u tom smislu svakako treba biti i „otvoreni” eksperiment u kojem će ispitanici sami davati odgovore, a ne birati ih među ponuđenima.

Na Slici 2 prikazani su rezultati mjerenja vremena reakcije. U svakom eksperimentalnom uvjetu zabilježeno je prosječno vrijeme koje je ispitaniku bilo potrebno za davanje odgovora. Rezultati sudionika u različitim uvjetima uspoređeni su analizom varijance koja je pokazala da postoji statistički značajna razlika u vremenu koja je potrebno za davanje odgovora u različitim uvjetima $(F(2,62)=$ 4,87; $\left.p<0,05 ; \eta_{\mathrm{p}}{ }^{2}=0,136\right)$. Post-hoc usporedba t-testovima za zavisne uzorke uz Bonferronijevu korekciju pokazala je da je vrijeme zabilježeno uz nezavisnosložene rečenice bilo statistički značajno kraće od vremena koja je bilo potrebno za davanje odgovora u rečenicama u kojima je glavna surečenica bila prva, a zavisna druga $(t(31)=2,73 ; p<0,05$ Cohenov $d=0,48)$. Razlika između vremena potrebnog za davanje odgovora na nezavisnoložene rečenice i one u kojima je zavisna 
surečenica prva, a glavna druga nije bila statistički značajna $(t(31)=2,04 ; p>$ $0,05)$ kao ni razlika u vremenu reakcije na dvije vrste subordiniranih rečenica $(t(31)=1,34 ; p>0,05)$. Budući da u vrijeme reakcije nije uključeno vrijeme potrebno za čitanje stimulusa, možemo zaključiti kako je na razlike utjecala struktura, a ne duljina rečenice koja sadrži antecedent. Međutim, kao što je već navedeno, nije sasvim jasno utječe li struktura na produljeno vrijeme odluke ili prisjećanja.

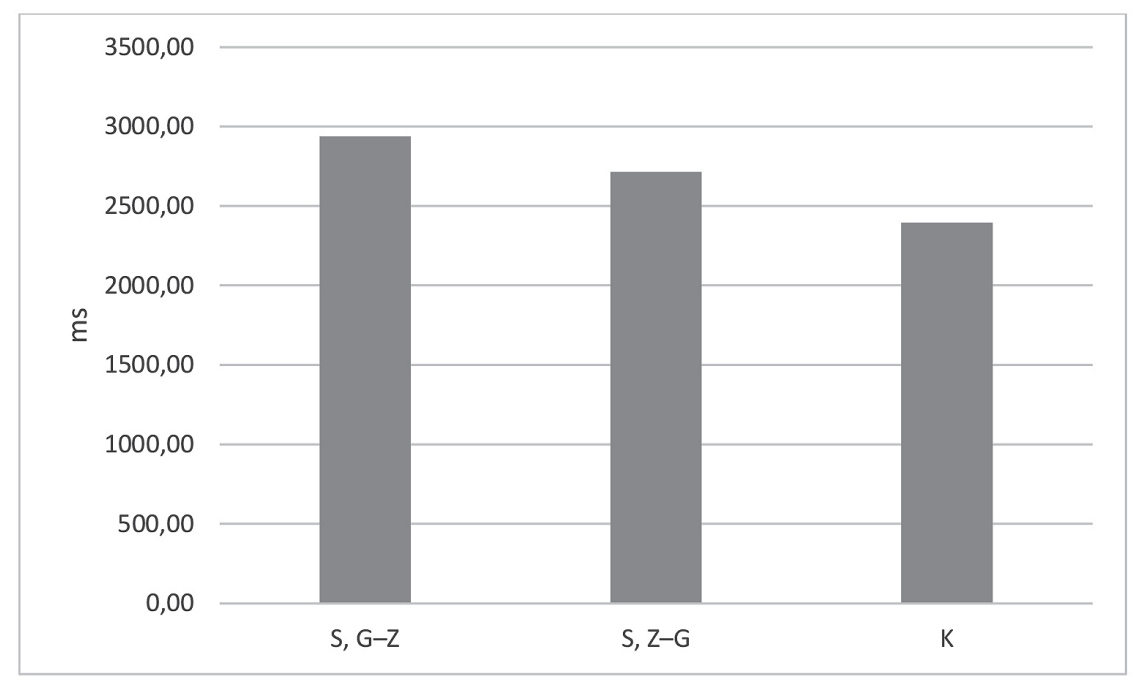

Slika 2. Prosječno vrijeme reakcije izraženo u milisekundama (aritmetičke sredine) u različitim eksperimentalnim uvjetima

\section{Zaključak}

$\mathrm{U}$ ovom je radu istražen utjecaj sintaktičke strukture diskursa na razumijevanje elipse glagolske skupine koja otvara mogućnost višestruke interpretacije. Dominantna strategija kojom su ispitanici razrješavali elipsu bio je izbor koordinirane strukture, u visokom broju slučajeva i u nezavisnosloženim koordiniranim i u zavisnosloženim rečenicama. U skladu s hipotezom glavne tvrdnje potvrdile smo da se i u hrvatskom, kao i u engleskom za koji je ta hipoteza postavljena, antecedent eliptičnih rečenica kojima prethode zavisnosložene rečenice češće bira iz glavne surečenice, nego iz zavisne. Dodatno, a u skladu s prethodnim istraži- 
vanjima slaganja u rodu i istraživanjima relativnih rečenica, rezultati istraživanja upućuju na zaključak prema kojem i načelo recentnosti, odnosno redoslijed glavne i zavisne surečenice, igra ulogu u procesiranju diskursa u hrvatskom jeziku, a isti je efekt uočen i kad elipsi prethodi nezavisnosložena rečenica. Uz to, rezultati interpretacije eliptične rečenice kojoj prethodi nezavisnosložena koordinirana rečenica u skladu su i s hipotezom domene koordinacije prema kojoj je u obradi koordinirane strukture dostupna čitava koordinirana struktura ili samo recentna sastavnica. Ipak, u odnosu na rezultate ispitivanja gramatičkoga slaganja s koordiniranom strukturom u hrvatskom jeziku, $\mathrm{u}$ interpretaciji ispitivanih eliptičnih struktura utjecaj recentnosti nije prevladao u odabiru antecedenta.

\section{Literatura:}

Aelbrecht, Lobke; William Harwood. 2014. To be or not to be elided: VP ellipsis revisited. Lingua 153. 66-97.

Arregui, Ana i DR. 2006. Processing elided verb phrases with flawed antecedents: The recycling hypothesis. Journal of memory and language 55/2. 232-246.

BošKović, ŽELJKo. 2014. Now I'm a phase, now I'm not a phase: On the variability of phases with extraction and ellipsis. Linguistic Inquiry 45. 27-90.

Caplan, Davin. 1972. Clause boundaries and recognition latencies for words in sentences. Perception and Psychophysics 12. 73-76.

Cuetos, Fernando; Mitchell, Don C. 1988. Cross-linguistic differences in parsing: Restrictions on the use of the Late Closure Strategy in Spanish. Cognition 30. 73-105.

Culicover, Peter W.; Jackendoff, Ray. 2005. Simpler Syntax. Oxford University Press. New York - Oxford.

FrAZIER, LYN. 1979. On comprehending sentences: syntactic parsing strategies. Doktorski rad. Sveučilište u Connecticutu. Storrs.

Frazier, Lyn; Clifton, Charles. 2005. The Syntax-discourse Divide: Processing Ellipsis. Syntax 8/2. 121-74.

Frazier, Lyn; Fodor, Janet Dean. 1978. The sausage machine: A new two-stage parsing model. Cognition 6/4. 291-325.

Garnham Jane; OAkhill, Kate; Cain, Allan. 1998. Selective Retention of Information about the Superficial Form of Text: Ellipses With Antecedents in Main and Subordinate Clauses. The Quarterly Journal of Experimental Psychology: Section A 51/1. 19-39.

GiBSOn, EdWARD. 1998. Linguistic complexity: Locality of syntactic dependencies. Cognition 68/1. 1-76. 
Gibson, Edward. 1991. A computational theory of human linguistic processing: Memory limitations and processing breakdown: Doktorska disertacija. Sveučilište Carnegie Mellon. Pittsburgh.

GinzBurg, Jonathan; SAG, Ivan. 2000. Interrogative Investigations. Stanford. CSLI publications.

Gordon, Peter C.; Hendrick, Randall. 1998. The representation and processing of coreference in discourse. Cognitive science 22/4. 389-424.

Grosz, Barbara J.; Weinstein, Scott; Joshi, Aravind K. 1995. Centering: A framework for modeling the local coherence of discourse. Computational linguistics 21/2. 203-225. Hankamer, Jorge; Sag, Ivan. 1976. Deep and Surface Anaphora. Linguistic Inquiry 7/3. 391-428.

Hardt, Daniel. 1993. Verb Phrase Ellipsis: Form, Meaning, and Processing. Doktorski rad. University of Pennsylvania. Philadelphia.

JARVella, RoBert J. 1971. Syntactic processing of connected speech. Journal of Verbal Learning and Verbal Behavior 10. 409-416.

Johnson, Kyle. 2001. What VP ellipsis can do, and what it can't, but not why. The handbook of contemporary syntactic theory. Ur. Baltin, Mark; Collins, Chris. Blackwell Publishers. Oxford. 439-479.

Kertz, Laura. 2013. Verb Phrase Ellipsis: The View from Information Structure. Language 89/3. 390-428.

Kim, Christina S. I DR. 2011. The Acceptability Cline in VP Ellipsis. Syntax 14/4. 318354.

Kimball, John. 1973. Seven principles of surface structure parsing in natural language. Cognition 2/1. 15-47.

Lobeck, Anne. 1995. Ellipsis: Functional heads, licensing and identication. Oxford University Press. New York.

Lovrić, Nenad; Fodor, JANet D. 2000. Relative clause attachment in sentence parsing. Poster izložen na 13. godišnjoj CUNY konferenciji o sintaktičkoj obradi (13th annual CUNY conference on human sentence processing). City University of New York.

Martin, Andrea E.; McElree, Brian. 2008. A Content-Addressable Pointer Mechanism Underlies Comprehension of Verb-Phrase Ellipsis. Journal of Memory and Language 58/3. 879-906.

Matić, ANA I DR. 2019. Mjerenjem pokreta očiju do referenta relativnih rečenica. (u ovome broju).

Merchant, Jason. 2016. Ellipsis: A Survey of Analytical Approaches. Chicago. http:// home.uchicago.edu/merchant/writings.html (pristupljeno 20. prosinca 2018.). 
Merchant, Jason. 2013. Voice and ellipsis. Linguistic Inquiry 44. 77-108.

Merchant, Jason. 2001. The Syntax of Silence: Sluicing, Islands, and the Theory of Ellipsis. Oxford University Press. New York - Oxford.

Miller, Philip; Pullum, Geoffrey K. 2013. Exophoric VP ellipsis. The core and the periphery: Data-driven perspectives on syntax inspired by Ivan A. Sag. Ur. Norcliffe, Elisabeth; Hofmeister, Phillip. CSLI publications. Stanford. 5-32.

Murphy, Gregory L. 1985. Psychological explanations of deep and surface anaphora. Journal of Pragmatics 9. 171-198.

Pearlmutter, Neal J.; Gibson, Edward. 2001. Recency in verb phrase attachment. Journal of Experimental Psychology: Learning, Memory, and Cognition 27/2. 574.

Phillips, Colin; PARker, Dan. 2014. The psycholinguistics of ellipsis. Lingua 151. 78-95. Rоотн, Mats. 1992. Ellipsis redundancy and reduction redundancy. Proceedings of the Stuttgart ellipsis workshop 29. Ur. Berman, Steve; Hestvik, Arild. Sveučilište u Sttutgartu.

Ross, John Robert. 1967. Constraints on variables in syntax. Doktorski rad. Massachusetts Institute of Technology. Cambridge.

SAG, Ivan A. 1976. Deletion and logical form. Doktorski rad. Massachusetts Institute of Technology. Cambridge.

Schneider, Walter; Eschman, Amy; Zuccolotto, Anthony. 2002. E-Prime (Verzija 2.0). [Računalni program i priručnik]. Psychology Software Tools Inc. Pittsburgh.

Shapiro, Lewis P.; Hestvik, Arild. 1995. On-line comprehension of VP-ellipsis: Syntactic reconstruction and semantic influence. Journal of Psycholinguistic Research 24/6. 517-532.

StJepanović, Sandra. 1998. On the placement of Serbo-Croatian clitics: Evidence from VP ellipsis. Linguistic inquiry 29/3. 527-537.

The Etymologies of Isidore of Seville. 2006. Preveli i priredili: Barney, Stephen A., Lewis, W. J.; Beach, J. A.; Berghof, Oliver. Cambridge University Press. Cambridge.

Van Craenenbroeck, Jeroen. 2017. VP-Ellipsis. The Wiley Blackwell Companion to Syntax, Second Edition. Ur. Everaert, Martin; Van Riemsdijk, Henk C. Wiley. 1-35.

Willer-Gold, JANA. 2013. Minimalistički pristup strukturi glagolskih skupina sa složenom dopunom u hrvatskome jeziku. Doktorski rad. Filozofski fakultet Sveučilišta u Zagrebu. Zagreb. 324 str.

Willer-Gold, Jana I DR. 2018. When linearity prevails over hierarchy in syntax. Proceedings of the National Academy of Sciences 115/3. 495-500.

Willer-Gold, JANA I DR. 2016. Conjunct agreement and gender in South Slavic: From theory to experiments to theory. Journal of Slavic linguistics 24/1. 187-224.

Williams, Edwin S. 1977. Discourse and logical form. Linguistic Inquiry. 101-139. 
Winkler, Susanne; Schwabe, Kerstin. 2003. Exploring the interfaces from the perspective of omitted structures. The interfaces: Deriving and interpreting omitted structures. Ur. Winkler, Susanne; Schwabe, Kerstin. John Benjamins Publishing. Amsterdam Philadelphia. 1-26.

\section{On the Form and Type of Information in Language Processing: the Choice of Antecedent of VP Ellipsis in Croatian}

\section{Abstract}

Psycholinguistic research of language processing has provided evidence that memory for the syntactic structure, as opposed to memory of the meaning of the utterance, is short lived, especially across the sentence boundaries (Caplan 1972, Jarvella 1971). However, the syntactic structure of the preceding text influences processing and interpretation of the ellipsis. (Hankamer and Sag 1976, Shapiro and Hestvik 1995). Frazier and Clifton (2005) formulated the (1) Main Assertion Hypothesis (MAH): comprehenders prefer to relate material in a new sentence to the main assertion of the preceding sentence; (2) Conjunction Domain Hypothesis: the processing of conjunction allows either the entire conjoined phrase to be processed or just the closer conjunct. These hypotheses are experimentally confirmed in the study of the interpretation of ambiguous elliptical sentences (Frazier and Clifton 2005). In this paper we experimentaly test the role of the Main Assertion Hypothesis and the Conjunction domain Hypothesis in the interpretation of VP ellipsis in Croatian. The differences in interpretation and reaction times were measured in comprehension task for two-sentenced discourses including complex sentences (e.g. Tina je otišla kući nakon što je popila piće. I Marija je. 'Tina went home after she had a drink. So did Marija.') and compound sentences (Tina je otišla kući $i$ popila piće. I Marija je. 'Tina went home and had a drink. So did Marija.'). Results suggest that the dominant strategy is choosing the cojoined structure as an antecedent of VP ellipsis. However, the effects of the main assertion and clause order are observed in the interpretation of the ellipsis following complex sentences. Results for the preferred interpretation of elliptical sentences that follow compound sentences confirm the Conjunction Domain Hypothesis i.e. the role of the clause order in processing.

Ključne riječi: elipsa glagolske skupine, zavisnosložene rečenice, nezavisnosložene rečenice, jezično procesiranje, hipoteza glavne tvrdnje, recentnost

Keywords: VP ellipsis, complex sentences, compound sentences, language processing, Main Assertion Hypothesis, recency 
